\title{
OBJECTIVITY VERSUS SUBJECTIVITY IN THE CONTEXT OF THE ICJ'S THREE-STAGE METHODOLOGY OF MARITIME BOUNDARY DELIMITATION
}

\author{
Fayokemi Olorundami*
}

\section{Introduction}

When the International Court of Justice (ICJ or the Court) handed down its decision in the first maritime boundary delimitation case (the North Sea Continental Shelf Cases), ${ }^{1}$ it met with considerable criticism regarding the extent of subjectivity portrayed in the judgment. ${ }^{2}$ The primary reason for this was the ICJ's espousal and application of 'equitable principles' as the rule governing maritime boundary delimitation. ${ }^{3}$ Some scholars continued to attach this label to subsequent maritime delimitation decisions made on the basis of equitable principles. ${ }^{4}$ With successive cases moving away from the application of equitable principles in favour of the equidistance/relevant circumstances method or what the Court has, since the Black Sea case, ${ }^{5}$ christened its three-stage delimitation methodology, the label of subjectivity has largely been replaced with a new label, 'objectivity'. ${ }^{6}$ This paper assesses the accuracy of this change of label by examining the decisions of the Court and Tribunals in some recent delimitation cases. This paper argues that although subjectivity may be said to have reduced, the delimitation of maritime boundaries by the Court and Tribunals still cannot be regarded as objective and predictable as exemplified in the decisions discussed in this paper. Each of the three stages in the three-stage methodology, namely the drawing of a provisional equidistance line, the adjustment or shifting of this line based on the presence of relevant circumstances and the (dis)proportionality test are analysed to support this position. This paper identifies a

\footnotetext{
* University of Greenwich

${ }^{1}$ North Sea Continental Shelf Cases [1969] ICJ Rep 3.

${ }^{2}$ Please see the next section for some detail about these criticisms.

${ }^{3}$ North Sea Continental Shelf Cases (n 1) at p. 34, para 47; p. 48, para 85; p. 54, para 101(1).

${ }^{4}$ See Yoshifumi Tanaka, Predictability and Flexibility in the Law of Maritime Delimitation (Hart Publishing, Portland, 2006) at pp. 58-60. Tanaka argues that 'equitable principles will severely amplify the danger of subjectivity - which has unfortunately been proven in subsequent cases - while ruling out the objective method of equidistance.' Other scholarly opinions are set out in the next section.

${ }^{5}$ Maritime Delimitation in the Black Sea (Romania v. Ukraine) [2009] ICJ Rep 61.

${ }^{6}$ For example, Tanaka distinguishes between what he calls a 'result-oriented equity approach' (what is usually referred to as the equitable principles/relevant circumstances rule) and a 'corrective-equity approach' (the equidistance/special circumstances method). The former, he states, perpetuates subjectivity, whereas the latter encourages objectivity and predictability. See Tanaka (n 4) at pp. 123-25. Politakis also argues that by making a decision to apply the equidistance method in the Jan Mayen case, the Court deals with the 'somewhat unmanageable problems of equity, or equitable principles.' Although not expressly mentioned, this is a reference to the issues of subjectivity associated with the application of equitable principles. See George Politakis, 'The 1993 Jan Mayen Judgment: The End of Illusions?' (1994) 41(1) Netherlands International Law Review (NILR) 1-29, at p. 26. See also Nuno Antunes, 'The 1999 Eritrea-Yemen Maritime Delimitation Award and the Development of International Law' (2001) 50(2) International and Comparative Law Quarterly (ICLQ) 299-344, at pp. 318 and 338.
} 
fixation with following the three-stage methodology (even when inappropriate) as, ironically, the driver for subjectivity and unpredictability in maritime boundary delimitation decisions.

\section{From Equitable Principles to Equidistance}

In 1969, the ICJ was asked to state what rules and principles the parties were to apply in delimiting their maritime boundaries in the North Sea. Whereas Denmark and the Netherlands contended that the applicable rule was equidistance as provided for in Article 6 of the 1958 Convention on the Continental Shelf, ${ }^{7}$ Germany, which was not a party to that Convention, argued that the delimitation should leave to each party a just and equitable share of the continental shelf. ${ }^{8}$ Rejecting both arguments, the Court held that the fundamental rule governing entitlement ipso jure to the continental shelf was that the continental shelf was the natural prolongation of the land territory of the coastal State into and under the sea. ${ }^{9}$ This view was derived from the Truman Proclamation of 1945, which the Court regarded as the start of the positive law on the continental shelf. ${ }^{10}$ In keeping with this proclamation, the Court held that delimitation was to be effected on the basis of equitable principles, taking account of all relevant circumstances, so as to leave to a coastal State all those parts of the continental shelf that were a natural prolongation of its land territory. ${ }^{11}$

This decision met with considerable criticism from both members of the bench and scholars. Judge Tanaka stated that the Court's 'equitable principles' position does not and indeed cannot furnish any concrete criteria for delimitation. As the factors to be considered in order to give effect to the notion of equitable principles are diverse and incapable of objective evaluations, they are essentially useless in enabling States which seek to delimit their boundaries by agreement through negotiations reach a successful result. ${ }^{12}$ Similarly, Judge Sorenson opined that to introduce equity as the sole principle governing maritime delimitation is to create a situation of 'considerable legal uncertainty'. ${ }^{13}$ Moreover, Judge Koretsky noted that reference to 'equitable principles' is vague and opens the door for subjective and arbitrary evaluations. ${ }^{14}$ In tandem with these opinions, legal scholars have

\footnotetext{
${ }^{7}$ Ibid., at pp. 10-11.

${ }^{8}$ Ibid., at p. 11 .

${ }^{9}$ Ibid., at p. 31, para 43.

${ }^{10}$ Ibid., at pp. 32-33, para 47.

${ }^{11}$ Ibid., at p. 53, para 101.

${ }^{12}$ Ibid., at p. 196 (Dissenting Opinion of Judge Tanaka).

${ }^{13}$ Ibid., at p. 257 (Dissenting Opinion of Judge Sorenson).

${ }^{14}$ Ibid., at p. 166 (Dissenting Opinion of Judge Koretsky).
} 
argued that the decision of the Court tended more to one made ex aequo et bono rather than one based on set legal principles. ${ }^{15}$

Notwithstanding these criticisms, the applicability of equitable principles rather than equidistance was confirmed in the Gulf of Maine case, ${ }^{16}$ the Tunisia/Libya ${ }^{17}$ case and the Libya/Malta case. ${ }^{18}$ In the Gulf of Maine case, the Chamber noted that regarding equitable principles, 'their equitableness or otherwise can only be assessed in relation to the circumstances of each case....' and 'that what international law requires is that recourse be had in each case to the criterion, or the balance of different criteria, appearing to be most appropriate to the concrete situation. ${ }^{19}$ In the Tunisia/Libya case, the Court noted as a problem the fact that the word 'equitable' is used to characterise both the result and the means of achieving the result. Stating that the application of equitable principles must result in an equitable result, it opined that the result is predominant, whereas the principles are subordinate. Therefore a principle is equitable if it produces an equitable result. ${ }^{20}$ By this, the Court may be regarded as refuting the notion that certain principles are intrinsically equitable and therefore must be applied. The problem with this reasoning was the lack of objective criteria for determining what an equitable result is and by extension what constitutes equitable principles. In this regard, Jennings asks where the mental processes of the judges begin and whether the Court decides upon what it thinks is an equitable result first before proceeding to choose principles that it considers will give effect to the equitable result it has pre-decided. ${ }^{21}$ Jennings argues that the concept of 'equitable result' leads to 'pure judicial discretion and a decision upon nothing more than the Court's subjective appreciation of what appears to be a fair compromise of the claims of either side. ${ }^{22}$

In the Libya/Malta case, the Court stated the link between equitable principles and an equitable result when it noted that the former is important not just for a Court or Tribunal involved in adjudication but also the States, which during their negotiations to delimit their

\footnotetext{
${ }^{15}$ Wolfgang Friedmann, 'The North Sea Continental Shelf Cases - A Critique' (1970) 64(2) American Journal of International Law (AJIL) 229-240, at p. 236; Mark Igiehon, 'Present International Law on Delimitation of the Continental Shelf’ (2006) 8 International Energy Law and Taxation Review (IELTR) 208-215, at p. 211. For further critical analysis of the ICJ's position on equitable principles, see Tanaka (n 4) at pp. 58-61.

${ }^{16}$ Case Concerning Delimitation of the Maritime Boundary in the Gulf of Maine Area (Canada/United States of America) [1984] ICJ Rep 246.

${ }_{17}^{17}$ Continental Shelf (Tunisia/Libyan Arab Jamahiriya) [1982] ICJ Rep 18.

${ }^{18}$ Continental Shelf (Libyan Arab Jamahiriya/Malta) [1985] ICJ Rep 13.

${ }^{19}$ Gulf of Maine case (n 16) at p. 313, para 158.

${ }^{20}$ Tunisia/Libya case (n 17) at p. 59, para 70.

${ }^{21}$ Robert Jennings, 'Equity and Equitable Principles' (1986) 42 Annuaire Suisse de Droit International (ASDI) 27-38, at p. 31.

${ }^{22}$ Ibid.
} 
boundaries by agreement, are doing nothing more than seeking an equitable result. ${ }^{23}$ The Court proceeded to set out expressly what equitable principles consist of:

the principle that there is to be no question of refashioning geography, or compensating for the inequalities of nature; the related principle of nonencroachment by one party on the natural prolongation of the other, which is no more than the negative expression of the positive rule that the coastal State enjoys sovereign rights over the continental shelf off its coasts to the full extent authorized by international law in the relevant circumstances; the principle of respect due to all such relevant circumstances; the principle that although all States are equal before the law and are entitled to equal treatment, "equity does not necessarily imply equality" ... nor does it seek to make equal what nature has made unequal; and the principle that there can be no question of distributive justice. $^{24}$

By setting out what equitable principles consist of, it may be argued that the Court was making an effort to reduce the subjectivity and uncertainty that a blanket application of equitable principles might entail. Nevertheless, Judge Oda, dissenting, criticised this decision as lacking substance, without the capacity to display the essential qualities of consistency and predictability required by law, and involving a 'subjective appreciation of the circumstances. ${ }^{25}$ Similarly, Judge Schwebel, in his dissenting opinion in the Jan Mayen case, decried the highly subjective nature of equitable principles, stating that what is equitable 'is as variable as the weather of the Hague'. ${ }^{26}$

The above cases were decided when the law of sea was governed by customary law and the 1958 Convention on the Continental Shelf. ${ }^{27}$ However, the entry into force of the 1982 United Nations Convention on the Law of the Sea (LOSC) ${ }^{28}$ did not help matters as delegates at the Conference that produced the LOSC could not agree on a delimitation method. Consequently, LOSC Articles 74(1) and 83(1) simply require that delimitation 'be effected by agreement on the basis of international law, as referred to in Article 38 of the Statute of the International

\footnotetext{
${ }^{23}$ Libya/Malta case (n 18) at p. 39, para 46.

${ }^{24}$ Ibid., at pp. 39-40, para 46.

${ }^{25} \mathrm{Ibid}$., at $p$. 125, para 1 (Dissenting Opinion of Judge Oda).

${ }^{26}$ Maritime Delimitation in the Area between Greenland and Jan Mayen (Denmark v. Norway) [1993] ICJ Rep 38, at p. 120 (Dissenting Opinion of Judge Schwebel).

${ }^{27}$ Convention on the Continental Shelf (Geneva, 29 April 1958, in force 10 June 1964) 499 UNTS 311.

${ }^{28}$ United Nations Convention on the Law of the Sea (Montego Bay, 10 December 1982, in force 16 November 1994) 1833 UNTS 396.
} 
Court of Justice, in order to achieve an equitable solution.' In view of this, the Court has wide latitude to decide how it would reach the goal of 'an equitable solution'.

Sensitive to the criticism of lack of objectivity and predictability occasioned by the application of equitable principles for the delimitation of maritime boundaries, the Court developed what it now calls the three-stage delimitation methodology. Under this methodology, the Court begins by drawing a provisional equidistance line; it then checks whether there are any relevant circumstances which require the adjustment or shifting of the line in order to achieve an equitable solution. Last, it checks that the area accorded each State as a result of the first two steps is not disproportionate when compared with the length of its coasts. ${ }^{29}$ The Tribunal in the Barbados/Trinidad and Tobago Arbitration had noted that 'the need to avoid subjective determinations requires that the method used starts with a measure of certainty that equidistance positively ensures, subject to its subsequent correction if justified'. ${ }^{30}$ Thus, beginning delimitation by drawing an equidistance line is promoted as a means of arriving at objective delimitation decisions.

Although the three-stage methodology was confirmed in the Black Sea case, its development can be traced to the Jan Mayen case. In that case, the Court cited with approval the opinion of the Tribunal in the Anglo-French Arbitration ${ }^{31}$ that the provision of Article 6 of the 1958 Convention on the Continental Shelf requiring the use of the equidistance method to delimit boundaries except where special circumstances indicate otherwise, meant that where such special circumstances exist, the equidistance line should be varied or modified but not abandoned in favour of a different method of delimitation. ${ }^{32}$ Furthermore, the Court held that because the equidistance/special circumstances rule of Article 6 could be seen as expressing a general norm based on equitable principles, there was no appreciable difference between the result produced by the application of Article 6 and the result produced by the customary rule that delimitation be based on equitable principles. ${ }^{33}$

This position was endorsed in the Qatar v. Bahrain ${ }^{34}$ case where the Court held that the equidistance/special circumstances method of Article 6 of the 1958 Convention and equitable

\footnotetext{
${ }^{29}$ Black Sea case (n 5) at pp. 101-03, paras 115-22.

${ }^{30}$ (2006) 27 RIAA 147, at p. 230 para 306.

${ }^{31}$ Delimitation of the Continental Shelf between the United Kingdom of Great Britain and Northern Ireland, and the French Republic (United Kingdom v France) (1978) 18 RIAA 3.

${ }^{32}$ Ibid., at p. 116, para 249.

${ }^{33}$ Jan Mayen (n 26) at p. 58.

${ }^{34}$ Maritime Delimitation and Territorial Questions between Qatar and Bahrain (Qatar v Bahrain) [2001] ICJ Rep 40.
} 
principles under customary law were 'closely interrelated'. ${ }^{35}$ This move to introduce the equidistance method into the law on delimitation gained ground in the Cameroon v Nigeria ${ }^{36}$ case where the Court pronounced it as 'very similar' to equitable principles and proceeded to state that the application of the customary rule requiring delimitations to be based on equitable principles consisted in first drawing an equidistance line, and then assessing whether or not relevant circumstances existed that might inform the shifting or adjustment of the line. ${ }^{37}$ In essence, there was no difference between the equidistance method and equitable principles. So from rejecting equidistance in the early cases, the Court came to equate them with the equitable principles rule, and then declared boldly in the Black Sea case that it would always apply the three-stage methodology whenever it was required to effect a maritime boundary delimitation, unless compelling factors prevented it from so doing. ${ }^{38}$

This transition from equitable principles to equidistance has been commended as embodying qualities of objectivity and predictability. ${ }^{39}$ This writer disagrees with this position and argues that the application of each of the three stages in the methodology has been shown to be fraught with subjectivity and, consequently, unpredictability. The next section examines each of these three stages to support this position.

\section{The Three-Stage Methodology}

\section{Provisional Equidistance Line}

At this first stage of the three-stage methodology, an equidistance line is drawn using methods that are geometrically objective. ${ }^{40}$ The line should ideally be constructed using all base points on the coasts in order to arrive at a strict equidistance line. However, selectivity in the choice of base points has introduced subjectivity into this otherwise objective first stage. Now the term 'appropriate base points ${ }^{41}$ is used in the cases to justify the base points chosen by the Court/Tribunal. Anderson notes that equidistance lines have always been drawn using the nearest points on the baseline from which the breadth of the territorial sea is measured,

\footnotetext{
${ }^{35}$ Ibid., at p. 111, para 231.

${ }^{36}$ Land and Maritime Boundary between Cameroon and Nigeria (Cameroon v Nigeria: Equatorial Guinea Intervening) [2002] ICJ Rep 303.

${ }^{37}$ Ibid., at p. 441, para 288.

${ }^{38}$ Black Sea case (n 5) at p. 101, para 116.

${ }^{39}$ Tanaka (n 4) at p. 130; G Guillaume, 'Speech by His Excellency Judge Gilbert Guillaume, President of the International Court of Justice, to the Sixth Committee of the General Assembly of the United Nations', available at http://www.icj-cij.org/court/index.php?pr=81\&pt=3\&p1=1\&p2=3\&p3=1; accessed 6 November 2016.

${ }^{40}$ Black Sea case (n 5) at p. 101, para 116.

${ }^{41}$ Ibid., at para 117.
} 
not from the "most appropriate base points. ${ }^{42}$ Likewise, in the Qatar v Bahrain case, the ICJ stated that 'the equidistance line is the line every point of which is equidistant from the nearest point on the baseline from which the breath of the territorial seas of each of the two States is measured. ${ }^{43}$ By endowing itself with the power to choose the most 'appropriate base points', there is ample scope for subjectivity. ${ }^{44}$ This gives cause for concern because the choice of base points inevitably affects the result from the construction of the equidistance line. ${ }^{45}$

In the Black Sea case, the Court excluded Serpent's Island as a source of base points in drawing the provisional equidistance line for the delimitation of the Exclusive Economic Zone (EEZ) and the continental shelf. ${ }^{46}$ The reason given by the Court was the fact that Serpent's Island was detached from the coast of Ukraine lying some 20 nautical miles away from the mainland and so could not be regarded as part of Ukraine's relevant coast as to do so would amount to grafting an extraneous component onto the coastline and therefore refashioning nature. ${ }^{47}$ However, this exclusion of Serpent's Island was unusual as the provisional equidistance line ought to have been drawn with base points chosen on the island and only in the second stage ought the Court to have considered whether or not the island had a disproportionate effect on the line necessitating the shifting or adjustment of the line. ${ }^{48}$ Briscoe and Prows note that the exclusion of Serpent's Island in the choice of base points 'added complexity and uncertainty to the delimitation. ${ }^{, 49}$ Similarly, Schofield states that ignoring Serpent's Island in the choice of base points amounts to refashioning nature and undermines the "clarity and consistency of the three-stage process. ${ }^{50}$ It would seem that the

\footnotetext{
${ }^{42}$ David Anderson, 'Recent Judicial Decisions Concerning Maritime Delimitation' in Lilian del Castillo (ed), Law of the sea: from Grotius to the International Tribunal for the Law of the Sea: liber amicorum Judge Hugo Caminos (Brill Nijhoff, Leiden, 2015) 493-511 at p. 504.

${ }^{43}$ Qatar v Bahrain case (n 34) at 94, para 177. See also LOSC Article 15.

${ }^{44}$ David Anderson, 'Maritime Delimitation in the Black Sea Case (Romania v. Ukraine)' (2009) 8(3) The Law $\&$ Practice of International Courts and Tribunals 305-327, at p. 317.

${ }^{45}$ Paul von Mühlendahl, 'Tiny Land Features in Recent Maritime Delimitation Case Law' (2016) 31(1) The International Journal of Marine and Coastal Law (IJMCL) 1-31, at p. 29.

${ }^{46}$ Black Sea case (n 5) at p. 109-110, para 149.

${ }^{47}$ Ibid.

${ }^{48}$ Coalter Lathrop, 'Maritime Delimitation in the Black Sea (Romania v. Ukraine)' (2009) 103(3) AJIL 543-549, at p. 548.

${ }^{49}$ Peter Prows and John Briscoe, 'The Role of Islands in the Generation of Boundaries at Sea' in Clive H Schofield, Moon-Sang Kwon, and Seokwoo Lee (eds), The Limits of Maritime Jurisdiction (Brill, Leiden 2013) 77-109 at p. 102.

${ }^{50}$ Clive Schofield, 'One Step Forwards, Two Steps Back? Progress and Challenges in the Delimitation of Maritime Boundaries since the Drafting of the United Nations Convention on the Law of the Sea' in Guifang Xue and Ashley White (eds), 30 years of UNCLOS (1982-2012): Progress and Prospects (China University of Political Science Press, Beijing, 2013) 217-239, at p. 238. Schofield also directed this criticism at the Bangladesh/Myanmar case where St Martin's Island was ignored in the choice of base points.
} 
Court ignored an objective geographical fact in order to arrive at a particular desired decision. $^{51}$

In keeping with these views, it is interesting to note that the ICJ had stated in this case that a consideration of relevant circumstances has no place at all in the first stage when the equidistance line is drawn as 'the line is plotted on strictly geometrical criteria on the basis of objective data. ${ }^{52}$ Yet when one considers that the effect of an island in a delimitation exercise is generally considered to be a relevant circumstance, ${ }^{53}$ suited for consideration not in the first but in the second stage, one observes that the Court effectively went against its stated position.

Base points were also selectively chosen in the Nicaragua v. Colombia case $^{54}$ and in the Bangladesh/Myanmar Arbitration. ${ }^{55}$ In the former, although certain Colombian islands generated entitlements to the east, base points were only chosen in respect of the western part, in spite of the Court's pronouncement that the entire coastline of the islands had to be taken into account. ${ }^{56}$ To explain its decision, the Court stated that although a large part of the relevant coasts lay to the east of the Colombian islands, it would deal with this problem as a relevant circumstance in the second stage of the three-stage methodology. ${ }^{57}$ For the Court, this difficulty in placing base points on the east of the Colombian islands did not detract from the drawing of a provisional equidistance line. Judge Abraham thus criticised this exercise arguing that the line drawn could not properly be called an equidistance line and therefore failed the test as an acceptable starting point. ${ }^{58}$ Here again, one can observe a lack of objectivity and predictability even though the equidistance method is being used.

In the latter case, the Tribunal ignored St Martin's Island in the choice of base points for the construction of the provisional line for the delimitation of the EEZ and the continental shelf, simply citing the Black Sea case as precedent, ${ }^{59}$ leading Cottier to cite it as an example of

\footnotetext{
${ }^{51}$ von Mühlendahl (n 45) at p. 30.

${ }^{52}$ Black Sea case (n 5) at p. 101 para 118.

${ }^{53}$ Tanaka (n 4) at p. 183; Malcolm Evans, 'Maritime Boundary Delimitation' in Donald Rothwell and others (eds), The Oxford Handbook of the Law of the Sea (Oxford University Press, Oxford, 2015) 254-279, at p. 273.

${ }^{54}$ Territorial and Maritime Dispute (Nicaragua v. Colombia) [2012] ICJ Rep 624.

${ }^{55}$ Maritime Boundary between Bangladesh and Myanmar in the Bay of Bengal (Bangladesh/Myanmar) ITLOS Reports 2012, 1.

${ }^{56}$ Nicaragua v. Colombia case (n 54) at p. 680, para 151.

${ }^{57}$ Ibid., at p. 697, paras 195-96.

${ }^{58}$ Ibid., at pp. 737-38, paras 27-31 (Separate Opinion of Judge Abraham).

${ }^{59}$ Bangladesh/Myanmar Arbitration (n 55) at p. 82, para 265.
} 
results not arrived at in a transparent manner. ${ }^{60}$ Similar criticisms levelled against the decision to ignore Serpent's Island in the Black Sea are also applicable with regard to the treatment of St Martin's Island in this case.

\section{Adjustment of the Equidistance line}

Adjustment of the equidistance line is the second stage in the ICJ's three-stage methodology, and subjectivity is manifested here, even more so than in the first stage. This stage involves the consideration of whether relevant circumstances exist to justify the shifting or adjustment of the provisional equidistance line in order to achieve an equitable solution. This is a reminder of Jennings' argument that what constitutes an equitable solution cannot be objectively articulated. Why is one solution considered equitable and another either not or more equitable than another?

Considering that the Court/Tribunal has to, in this stage of delimitation, weigh the applicable relevant circumstances, one may ask how this weighing is done. Currently, there is no objective means for this and it explains why States argue over whether a particular circumstance should be regarded as relevant or not, and what weight should be accorded it. In this regard, Evans opines that 'the exact means of assessing their impact and determining the necessary corrective is obscure. ${ }^{61}$ Elsewhere, he states that the exercise of weighing relevant circumstances is 'a remarkably vague one. ${ }^{62}$ Similarly, Antunes notes that the steps for identifying factors, weighing up their relative relevance, and translating that assessment into a line remain largely undefined. ${ }^{63} \mathrm{He}$ further notes a paucity of demonstrations of how the factors chosen by the Court informed the final line decided as constituting an equitable solution. ${ }^{64}$ Although Antunes acknowledges that some measure of subjectivity is inevitable due to the nature of judicial decision-making, he argues that this is not the same as arbitrariness. ${ }^{65}$ However, as shown below, in recent cases, the adjustment of the provisional equidistance line has displayed such considerable subjectivity that the value of the three-stage method has been thrown into doubt.

\footnotetext{
${ }^{60}$ Thomas Cottier, Equitable Principles of Maritime Boundary Delimitation: The Quest for Distributive Justice in International Law (Cambridge University Press, Cambridge, 2015) at 615.

${ }^{61}$ Malcolm Evans, 'Maritime Delimitation and Expanding Categories of Relevant Circumstances' (1991) 40(1) ICLQ 1-33, at p. 16.

62 Ibid., at p. 15.

${ }^{63}$ Nuno Antunes, Towards the Conceptualisation of Maritime Delimitation: Legal and Technical Aspects of a Political Process (Martinus Nijhoff Publishers, Leiden, 2003) at p. 271.

${ }^{64}$ Ibid., at pp. $265-266$.

${ }^{65}$ Ibid., at p. 269.
} 
In the Nicaragua $v$. Colombia case, Nicaragua argued against the application of the equidistance method, contending that its application could not lead to an equitable solution. This was due to the fact that the delimitation was between the mainland coast of Nicaragua and certain islands belonging to Colombia, rather than between two mainland coasts. Drawing a provisional equidistance line would deprive Nicaragua of a substantial part of the relevant area, since three-quarters of that area would be on the Colombian side. ${ }^{66}$ Moreover, adjusting or shifting the line could not lead to an equitable solution. Nicaragua therefore proposed the enclaving of the Colombian islands. ${ }^{67}$ The Court rejected this argument, holding that it was appropriate to remain faithful to its three-stage methodology and that although the problem involving diminution of a substantial part of the relevant area may constitute a relevant circumstance, this could only be addressed in the second stage of delimitation, where the Court adjusts the line to take account thereof. In order to shift the line, the Court decided on a weighting system where it gave a weighting of one to each Colombian base point and a weighting of three to each Nicaraguan base point. It thus constructed a line using a 3:1 ratio between the Nicaraguan and Colombian base points. ${ }^{68}$

This decision was criticised extensively, particularly by fellow judges. Judge Keith noted that the Court could have simply considered the peculiar geographical realities involved in the case and chosen a combination of methods to enable it reach an equitable solution, rather than hiding under the cloak of equidistance and in the process having to make 'major modifications in the application of the usual methodology. ${ }^{99}$ Judge Xue also questioned whether adjustment or shifting of the provisional equidistance line is equivalent to a total departure from the line. ${ }^{70}$ Similarly, Judge Abraham decried the extensive subjectivity applied in reaching the delimitation decision. He noted that although the Court affirmed that it was following its three-stage methodology, 'in reality, it diverges very considerably from it and actually it cannot do otherwise, since it is clear that the said method is inappropriate in the present case. ${ }^{, 71}$ Furthermore, Judge Abraham observed that the considerable shifting of the provisional equidistance line eastwards, closer to the Colombian islands, and the construction of two horizontal lines in order to delimit the area east of the Colombian islands, cannot be regarded as shifting or adjustments as they were totally unrelated to the provisional

\footnotetext{
${ }^{66}$ Nicaragua v. Colombia case (n 54) at pp. 693-94, para 185.

${ }^{67}$ Ibid., at p. 694, para 186.

${ }^{68}$ Ibid., at pp. 709-10, para 234.

${ }^{69}$ Ibid., at p. 745, para 13; p. 744, para 9 (Declaration of Judge Keith).

${ }^{70} \mathrm{Ibid}$., at p. 748, para 8 (Declaration of Judge Xue).

${ }^{71} \mathrm{Ibid}$., at p. 731, para 21 (Separate Opinion of Judge Abraham).
} 
equidistance line. ${ }^{72} \mathrm{He}$ concluded that the case is one in which the application of the threestage methodology was unsuitable and the Court could have acknowledged this rather than 'sacrifice clarity and intelligibility to the semblance of an illusory continuity." 73 This concern with 'illusory continuity' brings to the fore the fact that subjective decisions can be made in order to keep up appearances of following an objective method, namely, equidistance.

Incidentally, the Court defended itself by stating that '[f]ollowing this approach [equidistance/relevant circumstances] does not preclude very substantial adjustment to, or shifting of, the provisional line in an appropriate case.... ${ }^{74}$ What did the Court mean by 'very substantial adjustment'? Did it mean that it was entitled to draw a totally new line? Is the word 'substantial', qualified by the adjective 'very', compatible with the word 'adjustment', which in the context used in maritime boundary delimitation would mean 'to alter or move (something) slightly'? ${ }^{75}$ Is it also compatible with the word, 'shift', which means to move something to a different position or direction, slightly ${ }^{76}$ or over a small distance ${ }^{77}$ If then the Court thinks it is entitled to make 'very substantial adjustments' in order to arrive at an equitable solution, is it not safe to doubt the value of these adjustments insofar as it concerns objectivity and predictability?

Indeed the problem of subjectivity in adjusting provisional equidistance lines was again evident in the Bangladesh/Myanmar Arbitration. In that case, the Tribunal rejected Bangladesh's argument that the angle-bisector method be chosen for delimitation rather than adherence to the three-stage methodology. Insisting on following this methodology, the Tribunal drew a provisional equidistance line and proceeded to 'adjust' this line significantly in favour of Bangladesh by drawing a geodetic line starting at an azimuth of $215^{\circ}$ without giving any concrete reason for so 'adjusting'. Remarkably, Bangladesh had proposed the use of the angle-bisector method to draw the delimitation line starting at the same azimuth, prompting Judge Lucky, dissenting, to state:

\footnotetext{
${ }^{72}$ Ibid., at p. 738 , paras 32-33.

${ }^{73}$ Ibid., at p. 739, para 35.

${ }^{74}$ Ibid., at p. 697, para 197.

75 'Adjust - Definition of Adjust in English' (Oxford Dictionaries) available at http://www.oxforddictionaries.com/definition/english/adjust; accessed 5 February 2016.

76 'Shift Meaning in the English Dictionary' (Cambridge Dictionary) available at http://dictionary.cambridge.org/dictionary/english/shift; accessed 8 July 2016.

77 'Shift - Definition of Shift in English' (Oxford Dictionaries) available at http://www.oxforddictionaries.com/definition/english/shift; accessed 8 July 2016.
} 
I cannot agree with the view that the decision to use the $215^{\circ}$ azimuth line to determine the direction of the adjustment to the provisional equidistance line is not based on the angle-bisector methodology either in principle or in the adoption of the particular azimuth calculated by Bangladesh. ${ }^{78}$

The manner in which the Tribunal 'adjusted' the line starting at an azimuth of $215^{\circ}$ led to the call by Judges Nelson, Chandrasekhara Rao and Cot in their Joint Declaration for faithfulness to the equidistance/relevant circumstances method and a caution against super-imposing other methods of delimitation upon the equidistance/relevant circumstances method when implementing the latter. Failure to follow this caution, they stated, "would amount to reintroducing the very elements of subjectivity progressively reduced over the years. ${ }^{, 79}$ Although 'subjectivity' is a precise word for describing the Tribunal's adjusted line, the adjustment may also be described as a mystery to the parties and to a general audience. ${ }^{80}$ Indeed the way in which the Tribunal reached its conclusion that the azimuth of $215^{\circ}$ represented an equitable solution lacks transparency, particularly as no reason was given for this conclusion. ${ }^{81}$ Judge Cot in his separate opinion described the Tribunal's abandonment of the equidistance line for an azimuth line as 'a perversion of the [equidistance/relevant circumstances] methodology' ${ }^{82}$ Judge Ndiaye similarly noted that the Tribunal's change of course from the equidistance/relevant circumstances method to the angle-bisector method, whilst maintaining that it was following the former amounted to a 'contradiction and a logical paradox' ${ }^{83}$ In the absence of any concrete reason for choosing the azimuth line, the azimuth line has been described as one that seems to have "come out of nowhere. ${ }^{84}$ In view of this, it is logical to ask whether the word 'adjustment' means a license to substitute another line for the provisional equidistance line. ${ }^{85}$ Although this question should be answered in the negative, the reality is just as Judge Gao described: the whole adjustment exercise was excessive, unprecedented, manipulated and based on clearly subjective determinations. ${ }^{86}$

\footnotetext{
${ }^{78}$ Bangladesh/Myanmar Arbitration (n 55) at p. 54 (Dissenting Opinion of Judge Lucky).

${ }^{79}$ Ibid., at p. 2 (Joint Declaration of Judges Nelson, Chandrasekhara Rao and Cot).

${ }^{80}$ Xinjun Zhang, 'The ITLOS Judgment in the Bay of Bengal Case between Bangladesh and Myanmar' (2013),

12 Chinese Journal of International Law 1-75, at para 54.

${ }^{81}$ Bangladesh/Myanmar Arbitration (n 55) at pp. 5-6 (Declaration of Judge Wolfrum).

${ }^{82}$ Ibid., at p. 1 (Separate Opinion of Judge Cot).

${ }^{83}$ Ibid., at p. 33, para 97 (Separate Opinion of Judge Ndiaye).

${ }^{84} \mathrm{Ibid}$., at p. 20, para 50 (Separate Opinion of Judge Gao).

${ }^{85}$ Ibid., at pp. 14-25, paras 36-58.

${ }^{86}$ Ibid., at p. 21, para 53.
} 
One observation from the foregoing analysis is that the door is open to subjectivity when a Court/Tribunal is so bent on adhering to the equidistance/relevant circumstances method in order to project the image of objectivity, even when the geographical realities inform a departure from it. It would seem from the discussion above, therefore, that choosing a method different from equidistance may have prevented resort to subjective considerations in the 'adjustment' of the line. Judge Gao highlighted the fact that the inappropriateness of beginning with a provisional equidistance line made the subjective drawing of another line unavoidable. ${ }^{87}$ This was not different from the observation in the Nicaragua v. Colombia case, where the inappropriateness of employing the equidistance method led to a 'very substantial' adjustment of the equidistance line, provoking the comment that it may be necessary sometimes to depart from the standard method. ${ }^{88}$

Another case where subjectivity was evident even though the three-stage methodology was supposedly being followed was the arbitration between Bangladesh and India. ${ }^{89}$ Here again, the Tribunal rejected the proposal by Bangladesh to use the angle-bisector method, choosing rather to apply the equidistance/relevant circumstances method. Similar to the Tribunal's conclusion in the Bangladesh/Myanmar Arbitration, the Tribunal adjusted the provisional equidistance line to start at the azimuth of $177^{\circ} 30^{\prime} 00^{\prime \prime}$. This line, which the Tribunal did not explain how it was reached, bore close similarity with the azimuth of $180^{\circ}$ line proposed by Bangladesh using the angle-bisector method. ${ }^{90}$ Dr Rao thus opined that the considerations for so adjusting the line were arbitrary and legally unjustifiable, concluding that 'the majority subjectively shifted the provisional equidistance line to the $177^{\circ} 30^{\prime} 00^{\prime \prime}$ azimuth, the direction of which was not mandated by any observable criteria. ${ }^{91}$ When the Tribunal mentioned that its adjustment was to 'ameliorate the excessive negative impact' of the provisional equidistance line on the entitlement of Bangladesh to the continental shelf beyond 200 nautical miles and to achieve an equitable solution, without more, the Tribunal was

\footnotetext{
${ }^{87}$ Ibid., at p. 15 para 38.

${ }^{88}$ Nicaragua v. Colombia case (n 54) at p. 739, para 35 (Judge Abraham); p. 749, para 9 (Judge Xue); pp. 743 44, para 9 (Judge Keith).

${ }^{89}$ Bay of Bengal Maritime Boundary Arbitration between Bangladesh and India (Bangladesh v India), Award (7 July 2014).

${ }^{90}$ Ibid., at p. 147, para 478.

${ }^{91}$ Ibid., at p. 14, para 23 (Concurring and Dissenting Opinion of Dr P.S. Rao).
} 
leaving observers at a loss as to the verifiable factors that informed the decision and against which the decision might be assessed. ${ }^{92}$

Although some measure of subjectivity is inherent in the second stage of the three-stage methodology, because the Court is applying equity as a corrective function, it is submitted that this does not justify an adjustment that is so substantial as to be disturbing and unexplainable as exemplified in the cases analysed above. Scholars who praise the objectivity of the three-stage methodology hold that by beginning with equidistance and adjusting the equidistance line to make it equitable in the light of relevant circumstances, the quality of not only objectivity but also of flexibility required of the law is advanced..$^{93}$ In this context, flexibility of the law to suit individual geographical circumstances becomes a justification for the adjustment of the line. This writer is of the view that this explanation does not help matters, for allusions to flexibility may be a sly way of introducing subjectivity. Thus one may ask how this differs from the earlier cases where each case was regarded as a unicum, to be adjudged based on its individual merits and not subject to any compulsory delimitation method? Again, what is the value of an objective first stage that is marred by so much subjectivity in the second stage that the gains of the objective first stage are lost after all? This is in tandem with the view expressed by Cottier that in assessing predictability as a result of utilising the equidistance method, it is necessary to go beyond assessing only the value of the strict equidistance line, and consider the entire norm (that is equidistance and relevant circumstances combined), including the potential for adjustments to the 'objective' equidistance line. ${ }^{94}$

\section{The Disproportionality Test}

The disproportionality test, the last of the three-stage methodology, has not been the basis for adjusting a delimitation line recently. However, the Court and Tribunals have acknowledged that this test of proportionality is not a precise or mathematical one; rather it is the Court's broad assessment of whether a significant disproportion exists. ${ }^{95}$ The Tribunal in the Barbados/Trinidad and Tobago Arbitration stated that proportionality is used as a final check to ensure that the result of the application of the first two stages is equitable, not being tainted

\footnotetext{
92 Ibid., at p. 13, para 21; David Anderson, 'Bay of Bengal Maritime Boundary (Bangladesh v. India)' (2015) 109(1) AJIL 146-153, at p. 153.

93 See generally Tanaka (n 4).

${ }^{94}$ Cottier (n 60) at p. 385.

${ }^{95}$ Chile and Peru [2014] ICJ Rep 3, at p. 69, para 193.
} 
with gross disproportion (that is gross disproportion between the length of the coast and the area attributed to the State following the drawing and adjusting of the equidistance line). ${ }^{96}$

Following this line of thought, the ICJ in the Nicaragua v. Colombia case noted thus:

The Court thus considers that its task, at this third stage, is not to attempt to achieve even an approximate correlation between the ratio of the lengths of the Parties' relevant coasts and the ratio of their respective shares of the relevant area. It is, rather, to ensure that there is not a disproportion so gross as to "taint" the result and render it inequitable. Whether any disproportion is so great as to have that effect is not a question capable of being answered by reference to any mathematical formula but is a matter which can be answered only in the light of all the circumstances of the particular case. ${ }^{97}$

This may be contrasted with the mathematical accuracy of a strict equidistance line. Tanaka argues that because there are no objective criteria for calculating coastal lengths, the proportionality test performed on the basis of this calculation may be regarded as subjective. ${ }^{98}$ This position seems correct when one considers this dictum from the ICJ in the Black Sea case:

The Court cannot but observe that various tribunals, and the Court itself, have drawn different conclusions over the years as to what disparity in coastal lengths would constitute a significant disproportionality which suggested the delimitation line was inequitable and still required adjustment. This remains in each case a matter for the Court's appreciation, which it will exercise by reference to the overall geography of the area. ${ }^{99}$

One is here faced with the fact that a decision on proportionality is based on the circumstances of each particular case; this is a reminder of the same criticism levelled against the equitable principles/relevant circumstances rule of delimitation that the law of maritime delimitation would reek of subjectivity and display a lack of predictability if each case is considered as a unicum.

\footnotetext{
${ }^{96}$ Barbados/Trinidad and Tobago (n 30) at p. 214, paras 238-240.

${ }^{97}$ Nicaragua v. Colombia (n 55) at p. 716, para 242.

98 Yoshifumi Tanaka, 'Reflections on the Concept of Proportionality in the Law of Maritime Delimitation' (2001) 16 IJMCL 433-463, at p. 458.

${ }^{99}$ Black Sea case (n 5) at p. 129, para 213.
} 
In addition to the problem of calculating coastal lengths for determining the existence or otherwise of disproportionality, there is also the question of how any perceived disproportion is translated into an alteration of the line. There being no objective criteria for this, Evans describes the process as 'completely unpredictable'. ${ }^{100}$ For Higgins, ' $[t]$ he concept of proportionality in maritime delimitation remains, for me, full of uncertainties and problems. $^{101}$

It is apparent that one ought not to look for objectivity and predictability at this third stage of the methodology. Notwithstanding the foregoing, as this stage involves an ex post facto test for confirming the equitableness of the line, and in view of its limited recent use in the adjustment of the proposed delimitation line, it would seem that the disproportionality test is nearly redundant and that the more important stages are stages one and two, as shown from the analysis above, and it is those stages that bring cause for concern.

\section{Conclusion}

The equidistance/relevant circumstances rule, also known as the three-stage methodology, is now the general rule governing maritime boundary delimitation. Its use has been promoted as providing objectivity and predictability in the law of maritime boundary delimitation. This paper considered whether the three-stage delimitation methodology of the ICJ actually ensures that delimitation decisions are objective and predictable. The answer from the analysis is in the negative. From the choice of base points for drawing the provisional equidistance line to the adjustment of this line, the recent cases assessed in this paper have shown that considerable subjectivity and unpredictability exists within the application of the three-stage delimitation methodology. As Cottier notes '[i]t is one thing to define a methodology, but it is quite another to apply and realize it under the complex facts of a particular case. ${ }^{102}$ A common thread running through the cases discussed (with the exception of the Black Sea case) reveals that subjectivity is driven, ironically, by an unwillingness to depart from the methodology which has been touted as adequate for ensuring objectivity and predictability in the delimitation of maritime boundaries. It is submitted that it is unnecessary

\footnotetext{
${ }^{100}$ Malcolm Evans, 'Maritime Boundary Delimitation: Where Do We Go From Here?' in David Freestone, Richard Barnes and David Ong (eds), The Law of the Sea: Progress and Prospects (Oxford University Press, Oxford 2006) 137-160 at p. 153.

${ }^{101}$ Rosalyn Higgins, Problems and Process: International Law and How We Use It (Clarendon Press, Oxford 1994) 230.

${ }^{102}$ Cottier (n 60) at p. 621.
} 
to proceed with the three-stage methodology simply for the sake of standardisation, ${ }^{103}$ if clarity and objectivity will be sacrificed thereby.

${ }^{103}$ Nicaragua v. Colombia case (n 54) Declaration of Judge Xue, at pp. 748-49, para 9. 